\title{
A new species and redescription of two species of Euseius Wainstein (Acari: Phytoseiidae) from Cerrado biome areas in Brazil
}

Peterson R. Demite, Ana C. C. Cavalcante, Monique A. Dias \& Antonio C. Lofego

To cite this article: Peterson R. Demite, Ana C. C. Cavalcante, Monique A. Dias \& Antonio C. Lofego (2016) A new species and redescription of two species of Euseius Wainstein (Acari: Phytoseiidae) from Cerrado biome areas in Brazil, International Journal of Acarology, 42:7, 334-340, DOI: 10.1080/01647954.2016.1197311

To link to this article: https://doi.org/10.1080/01647954.2016.1197311

曲 Published online: 16 Jun 2016.

Submit your article to this journal $\pi$

Џ Article views: 50

View Crossmark data ¿ 


\title{
A new species and redescription of two species of Euseius Wainstein (Acari: Phytoseiidae) from Cerrado biome areas in Brazil
}

\author{
Peterson R. Demite $\mathbb{1}^{\mathrm{a}}$, Ana C. C. Cavalcante $\mathbb{1}^{\mathrm{a}}$, Monique A. Dias $\oplus^{\mathrm{b}}$ and Antonio C. Lofego $\mathbb{( 1}^{\mathrm{c}}$ \\ anstituto Federal Goiano - Câmpus Urutaí, Urutaí, Brazil; 'bPrograma de Pós-Graduação em Proteção de Plantas, Instituto Federal Goiano - Câmpus \\ Urutaí, Urutaí, Brazil; 'Departamento de Zoologia e Botânica, Instituto de Biociências, Letras e Ciências Exatas, Universidade Estadual Paulista, \\ UNESP, São José do Rio Preto, Brazil
}

\section{ABSTRACT}

A new species Euseius uai sp. n. Demite \& Lofego is described from the Minas Gerais State, Brazil. Euseius errabundus De Leon is recorded for the first time in Brazil and E. unisetus Moraes \& McMurtry is rediscovered. Both were collected in Goiás State, Brazil. A dichotomous key for the Brazilian Euseius species is presented.

\section{ARTICLE HISTORY}

Received 7 April 2016 Accepted 29 May 2016

Published online

15 June 2016

\section{KEYWORDS}

Amblyseiinae; Euseiini natural vegetation; redescription; rediscovery

\section{Introduction}

Phytoseiidae (Acari: Mesostigmata) include several species recognized as potential natural enemies of some agricultural insect and mite pests (Gerson et al. 2003; McMurtry et al. 2013, 2015), with about 2730 species described (Demite et al. 2014, 2016).

Euseius Wainstein is one of the largest genera within the Phytoseiidae, with about 190 valid species (Demite et al. 2014, 2016). Ten species were recorded from Brazil: Euseius alatus De Leon, E. citrifolius Denmark \& Muma, E. concordis (Chant), E. mesembrinus (Dean), E. inouei (Ehara \& Moraes), E. plaudus Denmark \& Muma, E. sakagamii (Ehara), E. sibelius (De Leon), E. unisetus Moraes \& McMurtry and E. vivax (Chant \& Baker). Recently, Lopes et al. (2015) considered E. brazilli and E. ho as junior synonyms of $E$. mesembrinus, and $E$. vivax was not considered a junior synonym of $E$. fructicolus (Gonzalez \& Schuster).

The Cerrado is the second largest Brazilian biome, exceeded only by the Amazon rainforest (Ribeiro and Walter 1998). It covers an area of approximately 2 million $\mathrm{km}^{2}$, representing nearly $22 \%$ of the Brazilian territory (Oliveira-Filho and Ratter 2002). This biome has a great concentration of endemic species subjected to strong human pressure, which has led to its classification as a "hotspot", i.e., a world priority conservation area (Myers et al. 2000). Despite its importance and great extension, few studies were conducted (most made in the last 15 years) on the mite fauna of this biome, and most of them in São Paulo State (Flechtmann 1967; Aranda 1974; Lofego et al. 2004, 2005, 2007; Oliveira et al. 2005; Lofego and de Moraes 2006), only a small and peripheral portion of the Cerrado. The greatest portions are concentrated in central regions of Brazil, mainly in Goiás, Mato Grosso, Mato Grosso do Sul, Minas Gerais and Tocantins states, where few studies have been conducted and that too recently (Demite et al. 2009; Rezende and Lofego 2011; Rezende et al. 2014).

This paper describes and illustrates a new species of the genus Euseius, record for the first time E. errabundus in Brazil. E. unisetus is rediscovered and the male is described for the first time.

\section{Materials and methods}

Mites were mounted on slides with Hoyer's medium and examined under a phase-contrast microscope. Illustrations were made using a drawing tube attached to the microscope. Dorsal and ventral setal nomenclature is that of Rowell et al. (1978) and Chant and Yoshida-
Shaul (1991), respectively. All measurements are given in micrometers $(\mu \mathrm{m})$, mean for all individuals measured, and (in parentheses) by the respective range (when variable). Measurements for the holotype are shown in bold type, before the mean. Measurements of types of Euseius unisetus Moraes \& McMurtry are provided [in brackets], those of holotype shown in bold type.

The voucher specimens of Euseius errabundus De Leon and E. unisetus are deposited in the collection of Acari of Departmento de Zoologia e Botânica, UNESP - Universidade Estadual Paulista, São José do Rio Preto, SP, Brazil.

\section{Results and Discussion}

\section{Euseius uai sp. n. Demite \& Lofego}

(Figures 1-7)

\section{Diagnosis}

Females with dorsal shield reticulate; $r 3$ on dorsal shield; all setae smooth, except $Z 5$ serrate; peritreme extending between the levels of $\mathrm{j} 3$ and $\mathrm{z2}$; ventrianal shield subpentagonal, without waist; JV1 transversaly aligned with JV2; calyx of spermatheca tubular, annulated, and atrium inconspicuous; macrosetae of leg IV spatulate.

\section{Type material (10 9 and $\left.20^{7}\right)$}

Holotype female, allotype male, seven paratype female and one paratype male: Comendador Gomes $\left(19^{\circ} 40^{\prime} 16^{\prime \prime} \mathrm{S}, 48^{\circ} 59^{\prime} 15^{\prime} \mathrm{W}\right)$, Minas Gerais State, Brazil, Pouteria ramiflora (Mart.) Radlk. (Sapotaceae), 26 May 2015, P.R. Demite and A.C.C. Cavalcante collectors, deposited at Departmento de Zoologia e Botânica, UNESP Universidade Estadual Paulista, São José do Rio Preto, SP, Brazil; three paratype females, same locality, host, data and collectors as holotype, deposited at Departamento de Entomologia e Acarologia, Universidade de São Paulo, Escola Superior de Agricultura "Luiz de Queiroz" (ESALQ/USP), Piracicaba, SP, Brazil.

\section{Description}

\section{Female}

Dorsum (Figure 1). Idiosomal setael pattern: 10A:9B/JV-3:ZV. Dorsal shield reticulate, in some areas reticulation weak, almost 

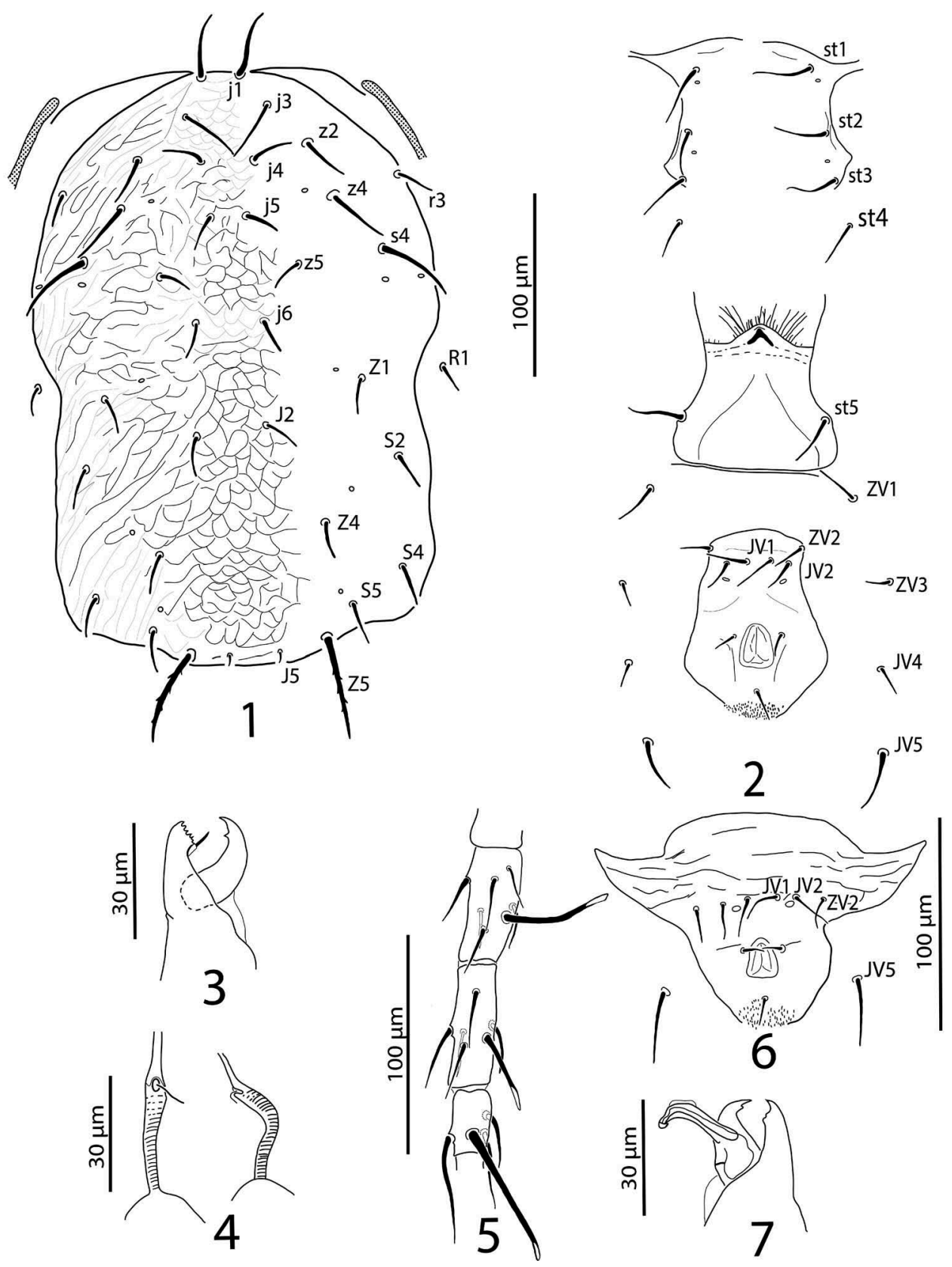

Figures 1-7. Euseius uai sp. n. Female: 1. Dorsal shield; 2. Ventral idiosoma; 3. Chelicera; 4. Spermatheca; 5. Genu, tibia and basitarsus of leg IV. Male: 6. Ventrianal shield; 7. Spermatodactyl.

imperceptible, 327325 (315-338) long, 220222 (210-236) wide at level of s4; setae: j1 3534 (31-36), j3 3435 (33-39), j4 2020 (19-22), j5 1920 (19-22), j6 2121 (19-22), J2 2021 (19-23), J5 8 8 (7-9), z2 3230 (27-32), z4 3333 (30-36), z5 2019 (18-20), Z1 2020 (19-22), Z4 2222 (21-25), Z5 5556 (46-61), s4 4544 (4047), S2 2424 (22-26), S4 2524 (22-27), S5 2726 (25-27), r3 2122 $(21-23)$ on dorsal shield, R1 1616 (15-16). All setae smooth, except Z5 serrate.

Venter (Figure 2). Sternal shield with three pairs of setae and two pairs of lyrifissures; distances between st 1 and st3 6262 (60-66), st2-st2 7372 (70-74); posterior margin of sternal shield and metasternal plate not visible; st 4 on unsclerotised cuticle; genital shield smooth; distance between st5 and st5 8379 (73-85). Ventrianal shield subpentagonal, without waist; JV1 transversaly aligned with JV2; with few striae; 103105 (102-111) long, 5556 (50-62) wide at level of ZV2 and 7475 (72-77) wide at level of anus, with three pairs of pre-anal setae (JV1, JV2 and ZV2) and a pair of pores posterior to JV2. Four pairs of opisthogastric setae on unsclerotized cuticle (JV4, JV5, ZV1 and ZV3); JV5 3736 (34-39). All ventral setae smooth.
Peritreme. Extending between the levels of $\mathrm{j} 3$ and $\mathrm{z} 2$.

Chelicera (Figure 3). Movable digit 2323 (22-25) long, with one tooth in addition to apical tooth; fixed digit 26 (25-27), with 5 5-7 teeth in addition to apical tooth and pilus dentilis.

Spermatheca (Figure 4). Calyx tubular, annulated, 2524 (22-27) long, atrium inconspicuous.

Legs (Figure 5). Macrosetae: Sgell 2627 (26-28), Sgelll 3332 (30-33), Stilll 3231 (30-32), SgelV 5053 (50-56), StilV 4041 (38-44), StIV 6766 (64-69). Macrosetae of leg IV spatulate. Chaetotatic formula of genu II: $2-2 / 0-2 / 0-1$ and of genu III: $1-2 / 1-2 / 0-1$

\section{Male}

Dorsum. Dorsal shield reticulate, 250-262 long and 200-226 wide; j1 28-29, j3 29-30, j4 18-20, j5 17-18, j6 18-21, J2 17-20, J5 7, z2 23-28, z4 29-31, z5 17-18, Z1 17-19, Z4 18-21, Z5 34-49, s4 36, S2 20-22, S4 20-23, S5 20-24, r3 18-20, R1 17-19. All setae smooth, except Z5 serrate. 
Peritreme. Extending beyond level z4.

Venter (Figure 6). Sternogenital shield smooth; ventrianal shield subtriangular, with transversal striae; 102 long and 140 wide at anterior corners, with three pairs of pre-anal setae, one pair of pores postero-mesad to JV2; JV5 33-34.

Spermatodactyl (Figure 7). Shaft 19-20 long.

Legs. Macrosetae smooth and spatulate; Sgell 23-24, Sgelll 27 Stilll 28, SgelV 38-39, StilV 33-36, StIV 57-58. Chaetotactic formula of genu II and III as in females.

\section{Etymology}

"uai" is a expression much used by the people who live in Minas Gerais, state of type locality of this species.
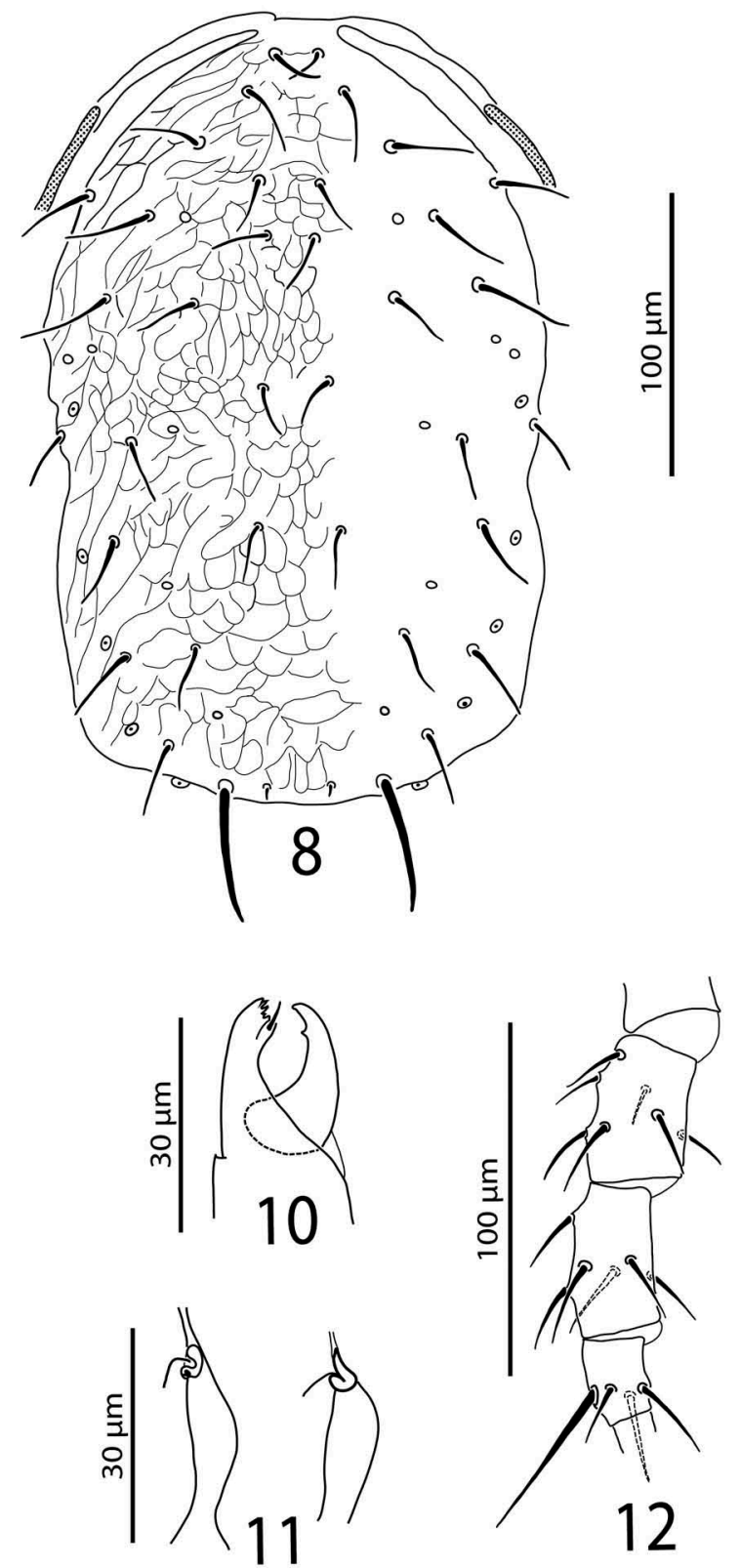

Euseius errabundus De Leon 1967: 19; de Moraes et al., 1986: 41, 2004: 66; McMurtry \& de Moraes 1989: 186; Aponte \& McMurtry, 1993: 151; Chant \& McMurtry 2005: 215, 2007: 120; Guanilo et al., 2008: 21; Demite et al., 2016.
This new species resembles Euseius dossei (Pritchard and Baker 1962) and Euseius victoriensis (Womersley 1954) due to similar shape and setal positions on the ventrianal shield (females), and by having macrosetae spatulated on the legs. But differs from both in having the dorso-central setae approximately twice longer and dorsal shield completely reticulated, while $E$. dossei and $E$. victoriensis have reticulation only on lateral margins.

\section{Euseius errabundus De Leon (Figures 8-14)}
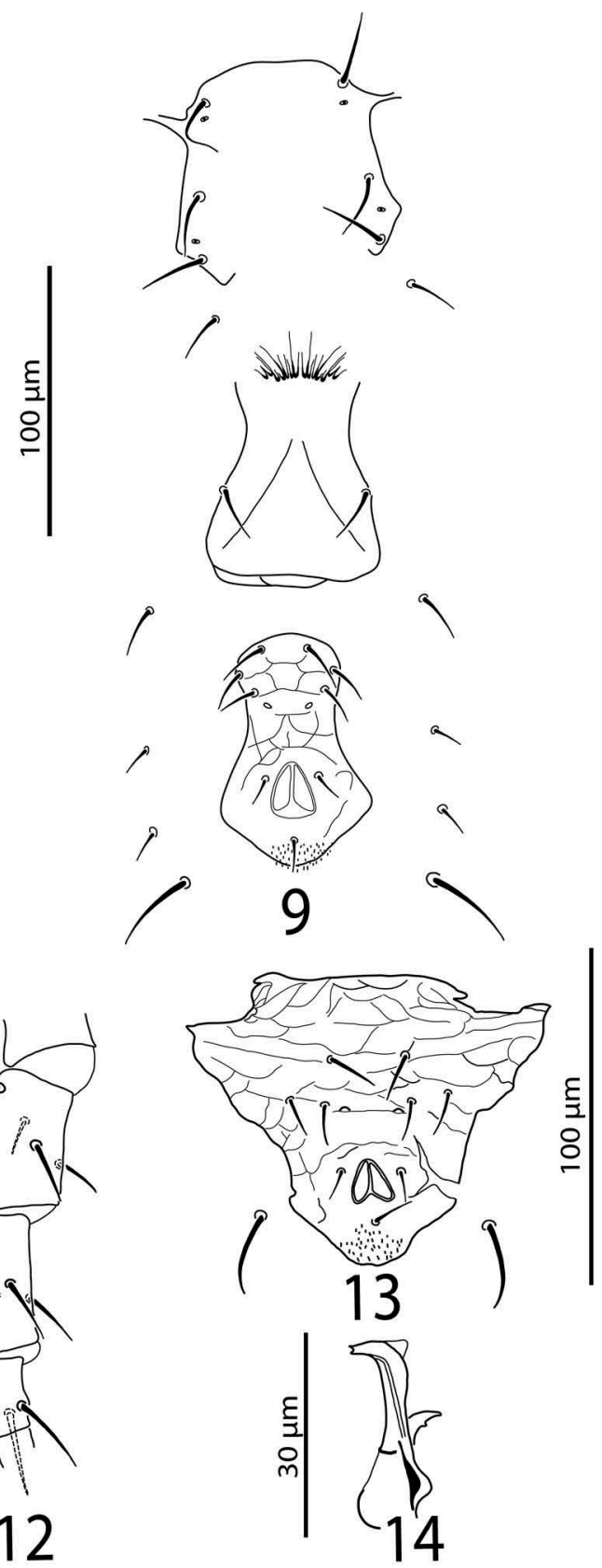

Figures 8-14. Euseius errabundus De Leon. Female: 8. Dorsal shield; 9. Ventral idiosoma; 10. Chelicera; 11. Spermatheca; 12. Genu, tibia and basitarsus of leg IV. Male: 13 . Ventrianal shield; 14 . Spermatodactyl. 


\section{Material examined $\left(n=10 \bigcirc\right.$ and $\left.40^{\prime \prime}\right)$}

Four females, 18 February 2015, Urutaí $\left(17^{\circ} 28^{\prime} 12^{\prime \prime} \mathrm{S}, 48^{\circ} 12^{\prime} 20^{\prime \prime} \mathrm{W}\right)$, Goiás State, Brazil, on Cariocar brasiliense Camb., Caryocaraceae; 1

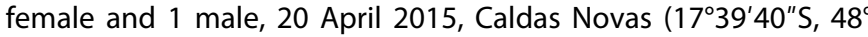
$\left.44^{\prime} 27^{\prime \prime} \mathrm{W}\right)$, Goiás State, Brazil, same host; 2 females and 1 male, 28 March 2015, Pires do Rio $\left(17^{\circ} 25^{\prime} 14^{\prime \prime} \mathrm{S}, 48^{\circ} 23^{\prime} 22^{\prime \prime} \mathrm{W}\right)$, Goiás State, Brazil, same host; 3 females and 2 males, 4 July 2015, Orizona $\left(16^{\circ}\right.$ 59'38"S, 48¹9'57"W), Goiás State, Brazil.

\section{Female}

Dorsum (Figure 8). Idiosomal setal pattern: 10A:9B/JV-3:ZV. Dorsal shield reticulate, 268 (265-275) long, 172 (167-180) wide at level of s4; setae: j1 24 (21-26), j3 27 (26-32), j4 22 (18-23), j5 22 (2024), j6 21 (19-24), J2 22 (20-25), J5 6 (5-6), z2 30 (28-32), z4 31 (26-35), z5 22 (19-25), Z1 25 (20-29), Z4 25 (21-29), Z5 50 (4554), s4 36 (33-40), S2 29 (26-32), S4 27 (22-30), S5 29 (25-31), r3 30 (25-31), R1 21 (20-23). All setae smooth.

Venter (Figure 9). Sternal shield with three pairs of setae and two pairs of lyrifissures; distances between st1 and st3 56 (5459), st2-st2 63 (61-65); posterior margin of sternal shield and metasternal plate not visible; st4 on unsclerotised cuticle; genital shield smooth; distance between st5 and st5 56 (5164). Ventrianal shield constricted between JV2 and anus level; reticulate; 85 (80-93) long, 38 (36-42) wide at level of ZV2 and 57 (52-60) wide at level of anus; with three pairs of pre-anal setae (JV1, JV2 and ZV2) and a pair of pores postero-mesad to JV2. Four pairs of opisthogastric setae on unsclerotised cuticle (JV4, JV5, ZV1 and ZV3); JV5 31 (27-33). All ventral setae smooth.

Peritreme. Extending to level of $z 2$.

Chelicera (Figure 10). Movable digit 20 (19-22) long, with one tooth in addition to apical tooth; fixed digit 22 (21-23), with 4-5 teeth in addition to apical tooth and pilus dentilis.

Spermatheca (Figure 11). Calyx tubular, inflated in the middle, 23 (20-24) long, atrium nodular.

Legs (Figure 12). Macroseta: StIV 44 (37-48), pointed. Chaetotatic formula of genu II: 2-2/0-2/0-1 and of genu III: 1-2/1-2/0-1.

\section{Male}

Dorsum. Dorsal shield reticulate, 216 (208-225) long and 154 (150-158) wide; j1 21 (20-22), j3 23 (22-24), j4 19 (17-20), j5 19 (17-21), j6 19 (18-20), J2 18 (16-20), J5 5 (5-6), z2 26 (24-27), z4 26 (24-29), z5 21 (19-24), Z1 21 (20-22), Z4 20 (18-22), Z5 35 (3436), s4 31 (28-34), S2 23 (19-25), S4 20 (18-21), S5 23 (20-25), r3 25 (23-27), R1 19 (18-20). All setae smooth.

Peritreme. Extending to level of $z 4$.

Venter (Figure 13). Sternogenital shield slightly reticulate; ventrianal shield subtriangular, reticulate; 89 (88-93) long and 118 (107$125)$ wide at anterior corners, with three pairs of pre-anal setae, one pair of pores mediad to bases of JV2; JV5 23 (22-26).

Spermatodactyl (Figure 14). Shaft 19 (18-20) long.

Legs. Macroseta: StIV 33 (31-35), blunt. Chaetotactic formula of genu II and III as in females.

\section{Remarks}

This is first record of this species for Brazil. The measurements of females collected in Goiás State are close of measurements of original description (De Leon 1967), except for the z2 longer (28-30) in comparison with the holotype (23).

\section{Previous records}

Peru, Trinidad and Venezuela (Demite et al. 2016).

\section{Euseius unisetus Moraes \& McMurtry (Figures 15-21)}

Euseius unisetus de Moraes \& McMurtry, 1983: 140; de Moraes et al., 1986: 56, 2004: 85; Chant \& McMurtry, 2005: 216; 2007: 123; Demite et al., 2016.

\section{Material examined $\left(n=3 \odot\right.$ and $20^{\prime \prime}+$ holotype + paratype $\left.q\right)$}

Two females and one male, 27 October 2015, Ipameri (17043'05"S $\left.48^{\circ} 08^{\prime} 31^{\prime \prime} \mathrm{W}\right)$, Goiás State, Brazil, on unknown plant; one female and one male, 10 November 2015, same locality, on Psidium guajava L. (Myrtaceae). Holotype: one female, 25 April 1980, Ouricuri, Pernambuco State; Paratype female: same date and locality as holotype. Holotype and paratype deposited at Departamento de Entomologia e Acarologia, Universidade de São Paulo, Escola Superior de Agricultura "Luiz de Queiroz" (ESALQ/USP), Piracicaba, SP, Brazil.

\section{Female}

Dorsum (Figure 15). Idiosomal setal pattern: 10A:9B/JV-3:ZV. Dorsal shield reticulate, [268 270] 265 (260-270) long, [172 173] 164 (155172) wide at level of $s 4$; with four pairs of lyrifissures and six pairs of pores; setae: j1 [17 17] 18 (17-19), j3 [18 20] 19 (19-20), j4 [14 15], 15 (15-16), j5 [16 17] 18, j6 [18 19] 21 (21-22), J2 [18 20] 21 (21-22), J5 [7 6] 7 (6-7), z2 [21 22] 22 (21-23), z4 [25 26] 25 (25-26), z5 [19 19] 19 (18-20), Z1 [20 22] 21 (19-23), Z4 [18 22] 20 (19-22), Z5 [52 50] 49 (47-50), s4 [27 28] 29 (29-30), S2 [23 22] 24 (22-26), S4 [20 20] 21 (20-21), S5 [20 22] 23 (21-25), r3 [27 26] 27 (25-30), R1 [17 17] 18 (17-18). All setae smooth, except $Z 5$ serrate.

Venter (Figure 16). Sternal shield with three pairs of setae and two pairs of lyrifissures; distances between st 1 and st3 [53 53] 55 (5455), st2-st2 [63 62] 61 (57-64); anterior margins and posterior of sternal shield and the metasternal plate not visible; st4 on usclerotised cuticle; genital shield smooth; distance between st5 and st5 [55 54] 58 (54-61). Ventrianal shield constricted at level of JV2; smooth; [82 83] 84 (81-86) long, [45 45] 45 (40-50) wide at level of ZV2 and [54 49] 64 (57-71) wide at level of anus; with three pairs of pre-anal setae (JV1, JV2 and ZV2) and a pair of pores postero-mesad of JV2. Four pairs of opisthogastric setae on unsclerotized cuticle (JV4, JV5, ZV1 and ZV3); JV5 [24 23] 24 (22-27). All ventral setae smooth. One metapodal plate visible.

Peritreme. Extending beyond level $\mathrm{j} 3$.

Chelicera (Figure 17). Movable digit [20] 20 long, with one tooth in addition to apical tooth; fixed digit [23] 22 (21-22), with [3] 3-4 teeth in addition to apical tooth and pilus dentilis.

Spermatheca (Figure 18). Calyx uniformly tubular [23 20] 23 (2025) long, atrium nodular.

Legs (Figure 19). Macroseta: StIV: [20 20] 20, knobbed. Chaetotatic formula of genu II: 2-2/0-2/0-1 and of genu III: 1-2/1-2/0-1.

\section{Male}

Dorsum. Dorsal shield reticulate, 210 long and $140-150$ wide; $j 115$, j3 17, j4 12-13, j5 13, j6 15-16, J2 15-17, J5 5, z2 15-16, z4 20-21, z5 16 , Z1 16, Z4 15-17, Z5 30-32, s4 21-22, S2 19-20, S4 16-17, S5 15-17, r3 20-21, R1 13-14. All setae smooth, except Z5 serrate.

Peritreme. Extending beyond level z4.

Venter (Figure 20). Sternogenital shield smooth; ventrianal shield reticulated, subtriangular; 77-78 long and 92-103 wide at 


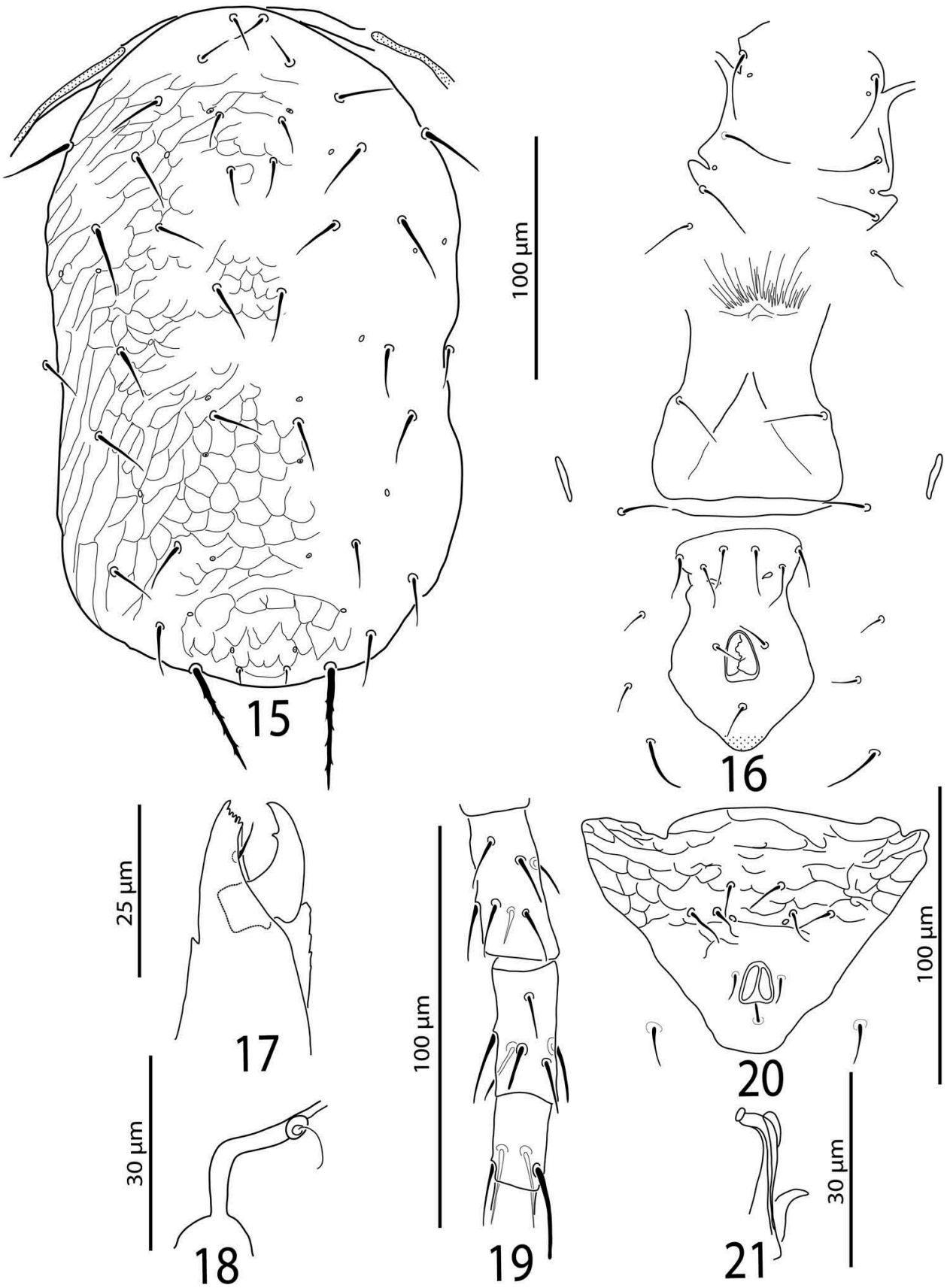

Figures 15-21. Euseius unisetus Moraes \& McMurtry. Female: 15. Dorsal shield; 16. Ventral idiosoma; 17. Chelicera; 18. Spermatheca; 19. Genu, tibia and basitarsus of leg IV. Male: 20. Ventrianal shield; 21. Spermatodactyl.

anterior corners, with three pairs of pre-anal setae (JV1, JV2 and ZV2), one pair of pores postero-mesad to bases of JV2; JV5 18-20.

Spermatodactyl (Figure 21). Shaft 12-15 long.

Legs. Macroseta: StIV 19-20, knobbed. Chaetotactic formula of genu II and III as in females.

\section{Remarks}

This species is found for the first time since its description. The male is described for the first time. The measurements of females collected in Ipameri, Goiás State are close to measurements of original description (de Moraes and McMurtry 1983).

\section{Previous records}

Brazil.

\section{Key to the Brazilian species of genus Euseius (females)*}

1 Dorsal shield smooth 2

1'. Dorsal shield reticulate 3

2 (1). Length of seta $z 4$ as or longer than the distance between their bases and bases $z 2$ E. concordis (Chant)

2 ' Length of setae $z 4$ corresponding to approximately half the distance between their bases and the bases of $z 2$ E. mesembrinus (Dean)

3 (1). Macroseta only on basitarsus of leg IV 4

3'. Macrosetae on genu, tibia and basitarsus of leg IV .............. 5

4 (3). Setae j3 and $z 4$ reaching bases of setae $z 2$ and s4, respectively; R1 inserted on dorsal shield; ventrianal shield reticulate; calyx of spermatheca tubular, inflated in the middle E. errabundus De Leon

4'. Setae j3 and z4 not reaching bases of setae z2 and s4, respectively; $\mathrm{R} 1$ inserted on unsclerotised cuticle; ventrianal 
shield smooth; calyx of spermatheca uniformly tubular ............. E. unisetus Moraes \& McMurtry

5 (3'). Seta JV1 next to anterior margin of ventrianal shield ........ E. plaudus Denmark \& Muma

5'. Seta JV1 approximately in transverse line with ZV2 and away from anterior margin of ventrianal shield

$6\left(^{\prime}\right)$. Genu III without macroseta E. sibelius (De Leon)

6'. Genu III with a macroseta 7

$\left.76^{\prime}\right)$. Setae $\mathrm{r} 3$ or R1 inserted on dorsal shield.

7'. Both $\mathrm{r} 3$ and $\mathrm{R} 1$ inserted on unsclerotised cuticle ${ }^{\prime}$.

8 (7). Setae $r 3$ inserted on dorsal shield and R1 on unsclerotised cuticle; macrosetae of leg IV spatulated

E. uai sp.n. Demite \& Lofego

8'. Setae $r 3$ inserted on unsclerotised cuticle and $R 1$ in the dorsal shield; macrosetae of leg IV knobbed ............ E. alatus De Leon

9 (7'). Macrosetae of leg IV blunt E. citrifolius Denmark \& Muma

9'. Macrosetae of leg IV knobbed .......... E. inouei (Ehara \& Moraes)

* Euseius sakagamii (Ehara) and E. vivax (Chant \& Baker) were not included in the present key as they were recorded in Brazil only one time each, by Ehara (1966) and Denmark and Muma (1973), respectively. These species were collected in São Paulo State, a region where several surveys of mite fauna have been conducted. However, they were not found again. Thus they are considered as questioned identifications.

\section{Acknowledgements}

We thank Dr. Gilberto José de Moraes (ESALQ-USP, Piracicaba, São Paulo, Brazil) for the loan of the type of specimen E. unisetus. We thank Dr. Marcus V.V. Ramos (IF Goiano, Urutaí, Goiás, Brazil) for the identification of the host plants. Financial support was provided by CNPq/FAPEG within the "Desenvolvimento Científico e Tecnológico Regional (DCR)" Program [Proc. no. 303016/2014-0]; M.A. Dias received a master's fellowship from FAPEG [Proc. 2015 10267000 909]; A.C. Lofego received a research productivity fellowship from CNPq [Proc. no. 304562/2015-7].

\section{Funding}

This work was supported by the CNPq/FAPEG within the "Desenvolvimento Científico e Tecnológico Regional (DCR)" Program; [303016/2014-0]; FAPEG; [2015 10267000 909]; CNPq; [304562/2015-7].

\section{ORCID}

Peterson R. Demite (D) http://orcid.org/0000-0001-6376-5463 Ana C. C. Cavalcante (D) http://orcid.org/0000-0002-1023-8579 Monique A. Dias (1) http://orcid.org/0000-0002-2359-7714 Antonio C. Lofego (D) http://orcid.org/0000-0002-3495-6858

\section{References}

Aranda CBR. 1974. Tetranychoidea (Acari) de uma área de Cerrado do Estado de São Paulo [Thesis]. Piracicaba (SP): Universidade de São Paulo; 47p.

Aponte O, McMurtry JA. 1993. Phytoseiid mites of Venezuela (Acari: Phytoseiidae). International Journal of Acarology 19:149-157.

Chant DA, McMurtry JA. 2005. A review of the subfamily Amblyseiinae Muma (Acari: Phytoseiidae) Part VI. The tribe Euseiini n. tribe, subtribes Typhlodromalina n. subtribe, Euseiina n. subtribe, and Ricoseiina n. subtribe. International Journal of Acarology 31:187-224.

Chant DA, McMurtry JA. 2007. Illustrated keys and diognoses for the genera and subgenera of the Phytoseiidae of the world
(Acari: Mesostigmata). West Bloomfield (MI): Indira Publishing House; 219p.

Chant DA, Yoshida-Shaul E. 1991. Adult ventral setal patterns in the family Phytoseiidae (Acari: Gamasina). International Journal of Acarology 17:187-199.

De Leon D. 1967. Some mites of the Caribbean Area. Part I. Acarina on plants in Trinidad, West Indies. Lawrence (KS): Allen Press; p. 1-66.

de Moraes GJ, McMurtry JA. 1983. Phytoseiid mites (Acarina) of Northeastern Brazil with description of four new species. International Journal of Acarology 9:131-148.

de Moraes GJ, McMurtry JA, Denmark HA. 1986. A catalog of the mite family Phytoseiidae. References to taxonomy, synonymy, distribution and habitat. Brasília (DF): EMBRAPA - DDT; 353p.

de Moraes GJ, McMurtry JA, Denmark HA, Campos CB. 2004. A revised catalog of the mite family Phytoseiidae. Zootaxa 434:1-494.

Demite PR, Feres RJF, Lofego AC, Oliveira AR. 2009. Plant inhabiting mites (Acari) from Cerrado biome of Mato Grosso State, Brazil. Zootaxa 2061:45-60.

Demite PR, McMurtry JA, de Moraes GJ. 2014. Phytoseiidae database: a website for taxonomic and distributional information on phytoseiid mites (Acari). Zootaxa 3795:571-577.

Demite PR, de Moraes GJ, McMurtry JA, Denmark HA, Castilho RdC. 2016. Phytoseiidae Database [Internet]. Piracicaba: Escola Superior de Agricultura "Luiz de Queiroz"-Universidade de São Paulo. Available from: http://www.lea.esalq.usp.br/phytoseiidae.

Denmark HA, Muma MH. 1973. Phytoseiidae mites of Brazil (Acarina, Phytoseiidae). Revista Brasileira de Biologia 33:235-276.

Ehara S. 1966. Some mites associated with plants in the State of São Paulo, Brazil, with a list of plant mites of South America. Japanese Journal of Zoology 15:129-149.

Flechtmann CHW. 1967. Ácaros de plantas do Cerrado. Anais da Escola Superior de Agricultura "Luiz de Queiroz" 24:315-316.

Gerson U, Smiley RL, Ochoa R. 2003. Mites for pest control. Oxford: Blackwell Science.

Guanilo AD, de Moraes GJ, Knapp M. 2008. Phytoseiid mites (Acari: Phytoseiidae) of the subfamily Amblyseiinae Muma from Peru, with description of four new species. Zootaxa 1880:1-47.

Lofego AC, de Moraes GJ. 2006. Ácaros (Acari) associados a mirtáceas (Myrtaceae) em áreas de Cerrado no Estado de São Paulo com análise faunística das famílias Phytoseiidae e Tarsonemidae. Neotropical Entomology 35:731-746.

Lofego AC, de Moraes GJ, Castro LAS. 2004. Phytoseiid mites (Acari: Phytoseiidae) on Myrtaceae in the State of São Paulo, Brazil. Zootaxa 516:1-18.

Lofego AC, Ochoa R, de Moraes GJ. 2005. Some tarsonemid mites (Acari: Tarsonemidae) from the Brazilian "Cerrado" vegetation, with descriptions of three new species. Zootaxa 823:1-47.

Lofego AC, de Moraes GJ, Ochoa R. 2007. Four new species of Xenotarsonemus (Acari: Tarsonemidae) from Brazil. Zootaxa 1646:1-15.

Lopes PC, McMurtry JA, de Moraes GJ. 2015. Definition of the concordis species group of the genus Euseius (Acari: Phytoseiidae), with a morphological reassessment of the species included. Zootaxa 4048:174-190.

McMurtry JA, de Moraes GJ. 1989. Some phytoseiid mites from Peru with descriptions of four new species (Acari: Phytoseiidae). International Journal of Acarology 15:179-188.

McMurtry JA, de Moraes GJ, Famah Sourassou N. 2013. Revision of the lifestyles of phytoseiid mites (Acari: Phytoseiidae) and implications for biological control strategies. Systematic and Applied Acarology 18:297-320.

McMurtry JA, Famah Sourassou N, Demite PR. 2015. The Phytoseiidae (Acari: Mesostigmata) as biological control agentes. In: Carrilo D, de Moraes GJ Peña JE, editors. Prospects for biological control of 
plant feeding mites and other harmful organisms. Cham $(\mathrm{CH})$ : Springer International Publishing; p. 133-149.

Myers N, Mittermeier RA, Mittermeier CG, da Fonseca GAB, Kent J. 2000. Biodiversity hotspots for conservation priorities. Nature 403:853-858.

Oliveira AR, Norton RA, de Moraes GJ. 2005. Edaphic and plant inhabiting oribatid mites (Acari: Oribatida) from Cerrado and Mata Atlântica ecosystems in the State of São Paulo, southeast Brazil. Zootaxa 1049:49-68.

Oliveira-Filho AT, Ratter JA. 2002. Vegetation physiognomies and woody flora of the Cerrado biome. In: Oliveira PS, Marquis RJ, editors. The Cerrados of Brazil: ecology and natural history of a neotropical savanna. New York (NY): Columbia University Press; p. 91-120.

Pritchard AE, Baker EW. 1962. Mites of the family Phytoseiidae from Central Africa, with remarks on genera of the world. Hilgardia 33:205-309.
Rezende JM, Lofego AC. 2011. Phytoseiidae (Acari: Mesostigmata) on plants of the central region of the Brazilian Cerrado. Acarologia 51:449-463.

Rezende JM, Lofego AC, Nuvoloni FM, Navia D. 2014. Mites from Cerrado fragments and adjacent soybean crops: does the native vegetation help or harm the plantation? Experimental and Applied Acarology 64:501-518.

Ribeiro JF, Walter BMT. 1998. Fitofisionomias do bioma Cerrado. In: Sano SM, Almeida SP, editors. Cerrado: ambiente e flora. Planaltina (DF): Embrapa-CPAC; p. 89-166.

Rowell HJ, Chant DA, Hansell RIC. 1978. The determination of setal homologies and setal patterns on the dorsal shield in the family Phytoseiidae (Acarina: Mesostigmata). The Canadian Entomologist 110:859-876.

Womersley H. 1954. Species of the subfamily Phytoseiinae (Acarina: Laelaptidae) from Australia. Australian Journal of Zoology 2:169-191. 